In conclusion, IRF4 gene analysis should be considered in patients of any age with Waldeyer's ring LBCL with germinal center origin, follicular and/or diffuse pattern, and strong MUM1 expression on pathological examination. The presence of IRF4 rearrangement may affect the prognosis of the disease and the duration of chemotherapy.

Keywords: Large B- cell lymphoma, Waldeyer's ring, IRF4, MUM1

Anahtar Sözcükler: Büyük B-hücreli lenfoma, Waldeyer halkası, IRF4, MUM1

\section{Authorship Contributions}

Surgical and Medical Practices: D.B., S.Ö., B.F.; Concept: B.F.; Design: D.B, B.F.; Data Collection or Processing: D.B., S.Ö., T.T., F.T.; Analysis or Interpretation: D.B., B.F.; T.T., F.T.; Literature Search: D.B.; Writing: D.B., S.Ö., T.T., B.F.

Conflict of Interest: No conflict of interest was declared by the authors.

Financial Disclosure: This research did not receive any specific grant from any funding agency in the public, commercial, or not-for-profit sectors.

\section{References}

1. Salaverria I, Philipp C, Oschlies I, Kohler CW, Kreuz M, Szczepanowski M, Burkhardt B, Trautmann H, Gesk S, Andrusiewicz M, Berger H, Fey M, Harder L, Hasenclever D, Hummel M, Loeffler M, Mahn F, Martin-Guerrero I, Pellissery S, Pott C, Pfreundschuh M, Reiter A, Richter J, Rosolowski M, Schwaenen C,

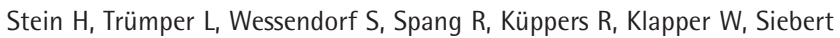
$\mathrm{R}$; Molecular Mechanisms in Malignant Lymphomas Network Project of the Deutsche Krebshilfe; German High-Grade Lymphoma Study Group; Berlin-Frankfurt-Münster-NHL trial group. Translocations activating IRF4 identify a subtype of germinal center-derived B-cell lymphoma affecting predominantly children and young adults. Blood 2011;118:139-147.

2. de Leval L, Bonnet C, Copie-Bergman C, Seidel L, Baia M, Brière J, Molina TJ, Fabiani B, Petrella T, Bosq J, Gisselbrecht C, Siebert R, Tilly H, Haioun C, Fillet $\mathrm{G}$, Gaulard P. Diffuse large B-cell lymphoma of Waldeyer's ring has distinct clinicopathologic features: a GELA study. Ann Oncol 2012;23:3143-3151.

3. Swerdlow SH, Campo E, Harris NL, Jaffe ES, Pileri SA, Stein H, Thiele J, Arber DA, Hasserjian RP, Lea Beau M, Orazi A, Siebert R. WHO Classification of Tumours of Haematopoietic and Lymphoid Tissues. Lyon, IARC Press, 2017.

4. Ramis-Zaldivar JE, Gonzalez-Farré B, Balagué $\mathrm{O}$, Celis V, Nadeu F, SalmerónVillalobos J, Andrés M, Martin-Guerrero I, Garrido-Pontnou M, Gaafar A, Suñol M, Bárcena C, Garcia-Bragado F, Andión M, Azorín D, Astigarraga I, Sagaseta de llurdoz M, Sábado $C$, Gallego $S$, Verdú-Amorós J, FernandezDelgado R, Perez V, Tapia G, Mozos A, Torrent M, Solano-Páez P, RivasDelgado A, Dlouhy I, Clot G, Enjuanes A, López-Guillermo A, Galera $P$, Oberley MJ, Maguire A, Ramsower C, Rimsza LM, Quintanilla-Martinez L, Jaffe ES, Campo E, Salaverria I. Distinct molecular profile of IRF4-rearranged large B-cell lymphoma. Blood 2020 23;135:274-286.

5. Ezzat AA, Ibrahim EM, El Weshi AN, Khafaga YM, AlJurf M, Martin JM, Ajarim DS, Bazarbashi SN, Stuart RK, Zucca E. Localized non-Hodgkin's lymphoma of Waldeyer's ring: clinical features, management, and prognosis of 130 adult patients. Head Neck 2001;23:547-558.

6. Poeschel V, Held G, Ziepert M, Witzens-Harig M, Holte $H$, Thurner L, Borchmann P, Viardot A, Soekler M, Keller U, Schmidt C, Truemper L, Mahlberg R, Marks R, Hoeffkes HG, Metzner B, Dierlamm J, Frickhofen N, Haenel M, Neubauer A, Kneba M, Merli F, Tucci A, de Nully Brown P, Federico $M$, Lengfelder E, di Rocco A, Trappe R, Rosenwald A, Berdel C, Maisenhoelder M, Shpilberg O, Amam J, Christofyllakis K, Hartmann F, Murawski N, Stilgenbauer S, Nickelsen M, Wulf G, Glass B, Schmitz N, Altmann B, Loeffler M, Pfreundschuh M; FLYER Trial Investigators; German Lymphoma Alliance. Four versus six cycles of CHOP chemotherapy in combination with six applications of rituximab in patients with aggressive B-cell lymphoma with favourable prognosis (FLYER): a randomised, phase 3, non-inferiority trial. Lancet 2020;394:2271-2281.

\title{
An Unconventional Presentation of Multiple Myeloma: Bazex Syndrome
}

\author{
Multipl Myelomun Olağan Dışı Bir Prezentasyonu: Bazex Sendromu
}

\author{
(D) Özlem Kandemir Alibakan1, (D) Naciye Demirel2, (D) Nihan Nizam³, (D) Rafet Eren² \\ 1 University of Health Sciences Turkey, Prof. Dr. Cemil Taşçığlu Training and Research Hospital, Clinic of Internal Medicine, Istanbul, Turkey \\ 2 University of Health Sciences Turkey, Prof. Dr. Cemil Taşçığlu Training and Research Hospital, Clinic of Hematology, İstanbul, Turkey \\ 3istanbul University Istanbul Faculty of Medicine, Department of Internal Medicine, istanbul, Turkey
}

\section{To the Editor,}

Multiple myeloma patients may exhibit signs and symptoms of skin involvement secondary to either malignant cell infiltration or disease-specific treatment. There are also anecdotal reports of paraneoplastic skin diseases including Sweet syndrome, leukocytoclastic vasculitis, and neutrophilic dermatosis associated with multiple myeloma [1]. In this report, we share a patient with a remarkably rare skin presentation of multiple myeloma. 
A 57-year-old female patient presented to the dermatology clinic with itching, discoloration, hardening, and exfoliation involving the hands, feet, head, and back. Physical examination revealed scalp scaling, hyperkeratosis of all fingernails on both hands and feet, yellowish discoloration, scaly plaques on the palms, thick yellow-gray crusts on the soles, and ichthyosiform appearance of the trunk (Figure 1a). Laboratory evaluation results were as follows: serum creatinine, $1.5 \mathrm{mg} / \mathrm{dL}_{\text {; }}$ total protein, $14.4 \mathrm{~g} / \mathrm{dL}$; albumin, $2.28 \mathrm{~g} / \mathrm{dL}$; corrected calcium, $11.74 \mathrm{mg} / \mathrm{dL}_{\text {; }}$ lactate dehydrogenase, $322 \mathrm{U} / \mathrm{L}_{\text {; hemoglobin, }}$ $6.9 \mathrm{~g} / \mathrm{dL}_{\text {; }}$ platelets, $103,000 / \mathrm{mm}^{3}$; and urine protein/creatinine ratio, $3.29 \mathrm{~g} /$ day. A skin lesion biopsy showed Bazex syndrome (acrokeratosis paraneoplastica) and she underwent an investigation to reveal a possible underlying malignancy. Upper and lower GI endoscopy and FDG PET-CT results were normal. She was referred to our clinic for hematologic evaluation. Due to her anemia, elevated creatinine level, and high total protein-to-albumin ratio, plasma cell dyscrasias were suspected and related tests were ordered. Serum immunofixation electrophoresis showed an IgG lambda monoclonal band. Serum free kappa light chain was $<6.50 \mathrm{mg} / \mathrm{L}$, free lambda light chain was $475 \mathrm{mg} / \mathrm{L}$, and $\beta 2$-microglobulin was $14 \mathrm{mg} / \mathrm{dL}$. The patient did not have polyneuropathy, organomegaly, volume overload, endocrinopathy, papilledema, thrombocytosis, or polycythemia and therefore POEMS syndrome was excluded. Bone marrow aspiration and biopsy confirmed plasma cell myeloma (95\% infiltration rate, CD38+, CD118+, CD56+, lambda+, kappa-, and Congo stain negative) and FISH was negative for $t(14 ; 16)$, $\mathrm{t}(4 ; 14), \mathrm{t}(11 ; 14)$, and del(17p13) mutations. The patient was started on bortezomib, cyclophosphamide, and dexamethasone chemotherapy along with topical steroids for the skin lesions as suggested by dermatology. After 4 cycles, her skin lesions were markedly regressed (Figure 1b). Bone marrow aspiration and biopsy showed remission and the patient was referred for autologous stem cell transplantation.

Bazex syndrome is characterized by hyperkeratosis of the acral regions, mostly seen in men over 40 years of age. Lesions are often seen on the nose and ears, and less frequently over acral areas such as the nails, hands, feet, knees, and elbows. Lesions appear as erythematous, violet-purple, and symmetrically distributed papulosquamous plaques $[2,3]$. Even though its exact etiology is unclear, possible proposed mechanisms include antibodies against the tumor cross-reacting with skin antigens, tumors secreting growth factors such as TGF- $\alpha$ that alter epidermal proliferation, and genetic susceptibility due to HLA-A3 and HLA-B8 [4]. Bazex syndrome may be associated with various malignancies, mostly with squamous cell carcinomas of the head and neck. However, it has also been shown to be associated with many other malignancies, including hematological malignancies [5].

In our literature search, we were able to find only one report of the association of multiple myeloma and Bazex syndrome [6]. This anecdotal association should be considered in patients investigated for Bazex syndrome.

Keywords: Bazex syndrome, Acrokeratosis paraneoplastica, Multiple myeloma, Paraneoplastic syndrome

Anahtar Sözcükler: Bazex sendromu, Akrokeratozis paraneoplastika, Multipl myelom, Paraneoplastik sendrom

Informed Consent: Verbal and written informed consent were obtained from the patient.

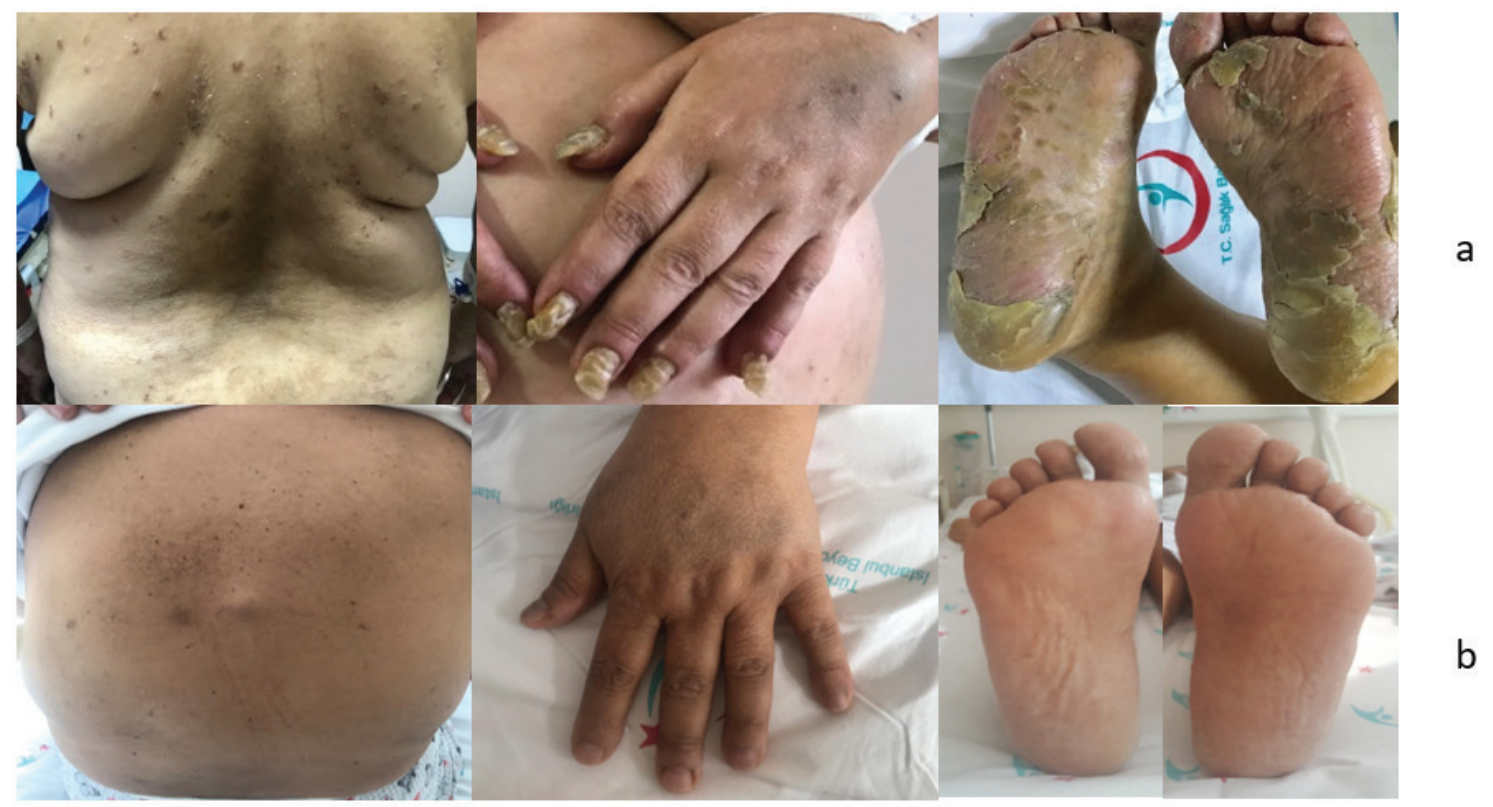

Figure 1. (a) Patient's lesions at presentation; (b) patient's lesions after chemotherapy. 


\section{Authorship Contributions}

Surgical and Medical Practices: Ö.K.A., R.E.; Concept: Ö.K.A., R.E., N.D.; Design: R.E., N.N.; Data Collection or Processing: Ö.K.A., R.E.; Analysis or Interpretation: N.D., R.E.; Literature Search: R.E., N.N.; Writing: N.N., R.E.

Conflict of Interest: The authors declare that they have no conflict of interest.

\section{References}

1. Bayer-Garner IB, Smoller BR. The spectrum of cutaneous disease in multiple myeloma. J Am Acad Dermatol 2003;48:497-507.
2. Chung VQ, Moschella SL, Zembowicz A, Liu V. Clinical and pathologic findings of paraneoplastic dermatoses. J Am Acad Dermatol 2006;54:745762.

3. Figueroa-Silva 0 , Espasandín-Arias M, Garcia-Martínez FJ, FernándezRedondo V, Toribio J. Is it just a psoriasiform dermatitis? Dermatol Online J 2017;23:13030/qt77k9w4c0.

4. Santos-Silva AR, Correa MB, Vargas PA, Almeida OP, Lopes MA. Bazex syndrome (acrokeratosis paraneoplastica) diagnosed in a patient with oral persistent ulcerations. Head Neck Pathol 2010;4:312-317.

5. Räßler F, Goetze S, Elsner P. Acrokeratosis paraneoplastica (Bazex syndrome) - a systematic review on risk factors, diagnosis, prognosis and management. J Eur Acad Dermatol Venereol 2017;31:1119-1136.

6. Gaveau D, Rotteleur G, Bauters F, Thomas P. Acquired acrokeratosis and ichthyosis associated with multiple myeloma. Ann Dermatol Venereol 1986;113:829-832.

๑Copyright 2020 by Turkish Society of Hematology

Turkish Journal of Hematology, Published by Galenos Publishing House

\title{
Case Report: An Infant with Severe Thrombocytopenia Diagnosed with Type 2B von Willebrand Disease Due To a De Novo p.Val1316Met Mutation
}

\author{
Olgu Sunumu: Ağır Trombositopenili Bir Bebekte De Novo p.Val1316Met Mutasyonuna Bağlı \\ Von Willebrand Hastalığı Tip 2B Tanısı
}

(1) Junjie Fan, (1) Jing Ling, (1) Huifeng Zhou, (1) Jie He, (1) Shaoyan Hu

Children's Hospital of Soochow University, Department of Hematology and Oncology, Jiangsu, China

\section{To the Editor,}

Type 2B von Willebrand disease (vWD 2B) is a rare disease that is difficult to diagnose. It usually presents with a normal or decreased platelet count with bleeding tendency. Clinically, it can be confused with immune thrombocytopenic purpura (ITP), which results in improper treatment. Herein, we report a case of an infant with severe thrombocytopenia diagnosed with vWD 2B.

The female infant was found to have some petechiae on her body when she was 6 days old. A routine blood test in a local hospital showed a decreased platelet count of $19 \times 10^{3} / \mu \mathrm{L}$, a low hemoglobin level of $100 \mathrm{~g} / \mathrm{L}$, and a normal white blood cell count of $12.1 \times 10^{3} / \mu \mathrm{L}$. Serum bilirubin was elevated to 19 $\mathrm{mg} / \mathrm{dL}$. Cranial ultrasound showed subependymal hemorrhage and bilateral intraventricular hemorrhage. After treatment with platelet transfusion, intravenous immunoglobulin, methylprednisolone, and vitamin K1, the baby's bilirubin and hemoglobin normalized and her platelet count increased to $80 \times 10^{3} / \mu \mathrm{L}$ initially, but it dropped down to approximately $20 \times 10^{3} / \mu \mathrm{L}$ thereafter.

At the age of 41 days, the infant was transferred to our hospital. On admission, the physical examination was unremarkable except for some ecchymosis on the body. Her family history included no family members with low platelet levels or with bleeding diathesis. Laboratory evaluations were notable for severe thrombocytopenia (platelet count: $16 \times 10^{3} / \mu \mathrm{L}$ ) but otherwise normal hemoglobin and white blood cell count values. The mean platelet volume was $13.4 \mathrm{fL}$ (normal range: 7.4-11 fL). A peripheral blood smear revealed nonspecific thrombocytopenia without platelet clumping. The antinuclear antibody investigation was negative, and the prothrombin time, activated 